Research Journal of Applied Sciences 7 (6): 322-328, 2012

ISSN: $1815-932 \mathrm{X}$

(C) Medwell Journals, 2012

\title{
Effect of Nickel on the Microflora of Gill, Gut and Skin of Clarias gariepinus
}

\author{
E.A.A. Olojo, N.A. Amusa and P.E. Omogbethai \\ Department of Plant Science and Applied Zoology, Olabisi Onabanjo University, \\ P.M.B. 2002, Ago-Iwoye, Ogun State, Nigeria
}

\begin{abstract}
A study was carried on the effect of nickel exposure on the miroflora of the skin and gut of African catfish, Clarias gariepinus. C. gariepinus of different stages was applied with nickel and monitored every $24 \mathrm{~h}$ over a period of $672 \mathrm{~h}$ in wooden vats under a laboratory condition. Eleven adult samples, thirty six post juvenile and thirty one juvenile samples were analyzed for the isolation of microflora using biochemical test. Both gram +ve and gram -ve bacteria were isolated. The gram -ve bacteria isolated were mainly rods and members of the Family Enterobacteriaceae including Proteus and Serratia. These species were more widely distributed in and more frequently isolated from the gut regions than the gram +ve bacteria which were represented by Streptococcus and Staphylococcus species. Proteus species and Streptococcus species isolated from the gut extracts were also found in the skin region. Bacillus species and Pseudomonas species were also found in both the skin and gut regions of the fish. The number and types of microbes in the skin and gut regions are similar.
\end{abstract}

Key words: Proteus, Serratia, species, nickel, Staphylococcus species, Nigeria

\section{INTRODUCTION}

The indigenous microflora of fish has been described for many purposes. This includes descriptions of microbial spoilage, relationship between environment and fish microflora (Horsley, 1977) the monitoring of changes in fish farms the nutritional role of the intestinal microflora (Moriarty, 1990) and the antibiotic resistance profile of the indigenous flora and the disease-preventive role of bacterial strains known as probiotics.

Contamination of aquatic system with heavy metals has become a matter of great concern over the past few decades. The source of heavy metals in aquatic environment may be through natural or anthropogenic sources. Natural sources include weathering of minerals and soils (Merian, 1991) while anthropogenic inputs are mainly from industrial effluents, domestic effluents, rural and urban storm, water run-off and spoil heaps (Agbozu and Ekweozor, 2001). The effect of heavy metals has consequently received the attention of several researchers (Annune and Iyaniwura, 1993; Baranowska-Bosiacka et al., 2000; Olojo et al., 2005; Van Vuren et al., 1994). However, information on the effect of metals on the microflora of fish is scarce.

Nickel is a naturally occurring metal existing in different basic ores namely arsenide, laterite, silicate and sulphate (Galvin, 1996). It is a natural ubiquitous element of the earth and in water (Snodgrass, 1980). Inhaled insoluble nickel increases the risk of cancer or gastrointestinal symptoms. Nickel inhalation exposure increases susceptibility to respiratory infection, allergic contact, dermatitis and pulmonary edema (Snodgrass, 1980).

Fish are able to accumulate and retain heavy metals from their environment (Pagenkopf, 1983). The accumulation of metals in tissues of fish is dependent upon exposure concentrations and duration as well as other factors such as salinity, temperature, hardness and metabolism of the animals (Allen, 1995). Fishes are bathed in aqueous solution of microbes. These microbes have the choice of living in association with the potential host (intestinal tract, gills or skins) or not.

Organisms may colonize the surface of the fish thereby, becoming part of the resident microflora. The presence of these microflora inhibits the arrival and subsequent colonization by other organisms that may be pathogenic to the fish. The microflora of living fish depends on the microbial contents of the water in which the fish live.

Fish microflora includes bacteria such as species of Pseudomonas, Alcaligenes, Vibrio, Micrococcus, Baccillus, etc. Surrounding bacteria are continuously ingested at a high rate from the culture water either with the feed or when the fish is drinking causing a natural

Corresponding Author: E.A.A. Olojo, Department of Plant Science and Applied Zoology, Olabisi Onabanjo University, P.M.B. 2002, Ago-Iwoye, Ogun State, Nigeria 
interaction between the microbiota of the ambient environment and the live food. Both human and animals need a normal bacterial flora in the digestive tract for protection against disease causing bacteria and production of compounds that are important for a well functioning digestion.

Probiotics are non-pathogenic and non-toxigenic organisms which retain viability during storage and survive passage through the small intestine and stomach. They benefit the host when grown in a particular microenvironment by inhibiting or preventing the growth of other biological organisms within the same microenvironment.

The prebiotics bacteria are the non-digestible food ingredients that selectively stimulate the growth and activity of beneficial microorganisms already present in the colons of humans (Gibson and Roberfroid, 1995). The ingestion of beneficial bacteria leads to colonization of the gut with the added strain and this strengthens the gastrointestinal barrier to disease.

In terms of microbial population, the stomach has very low bacterial numbers due to low environmental $\mathrm{pH}$ (Cummings et al., 1989). The bacterial population within the gastrointestinal tract of mammals constitutes a metabolically active organ that act as a barrier to infection by exogenous pathogenic microorganisms. While gastrointestinal microflora presents a microbial-based barrier to invading organisms, pathogens become established when the integrity of the microbes is under stress, antibiotic treatment or physiological alterations.

African catfish, Clarias gariepinus is an omnivore fresh water fish. It is suitable for culture because of its tolerance to adverse environmental conditions. It is of great commercial importance because it is the most common fresh water fish widely consumed in Nigeria (Olaifa et al., 2004). The numbers and types of bacteria inhabiting different portions of the digestive tract vary as a result of the $\mathrm{pH}$ and oxygen level within each region.

Generally, there is a progressive increase in the number of bacteria found in the gut with the stomach having the lowest numbers as a result of the low $\mathrm{pH}$, the small intestine has a large bacterial load while the most heavily colonized region is the colon (Gibson and Roberfroid, 1995).

\section{MATERIALS AND METHODS}

Thirty one juveniles of African catfish, Clarias gariepinus (mean Total Body Length $\mathrm{TB}$ Lin $\mathrm{cm}=$
$10.0 \pm 2.0$; mean body weight, $\mathrm{BW}$ in grams $0.03 \pm 0.02$ and 36 post-juveniles (mean TBL cm $19 \pm 2.3$; mean BW in grams $26 \pm 2.4$ and eleven adult (mean TBL in cm $38 \pm 7.0$; mean BW ingrams $580 \pm 5.0$ were obtained from a local fish farm. Fish were fed with commercially formulated floating feed and kept in three vats for 2 weeks to acclimatize before the commencement of the experiment.

The fish were divided into nine experimental vats $(5 \times 10 \times 4 \mathrm{ft})$ containing fresh water $(\mathrm{pH} \mathrm{7.7)}$ for $72 \mathrm{~h}$ before introducing the heavy metal. Dissolved nickel was introduced into the water in the form of nickel bicarbonate. Two concentrations of nickel $\mathrm{T}_{1}=0.06 \mathrm{mg} \mathrm{L}^{-1}$ and $\mathrm{T}_{2}=0.08 \mathrm{mg} \mathrm{L}^{-1}$ were used for each stage of the fish viz: juvenile, post juvenile and adult each having two replicates. The experiment lasted for 4 weeks.

Fish specimens were randomly selected, two from each vat at 2 weeks interval and transported to the laboratory for isolation, identification and biochemical characterization of microflora of the gut and skin.

Isolation from the skin was made while the fishes were alive. The fishes used were taken with hand-net and seized with the hand with sterile gloves. A sterile swab was rubbed along the skin. The swab immediately cultured on Nutrient Agar which had been prepared afore time. The swab spot on the medium was streaked out using a sterile inoculating loop. The plate was kept for incubation at room temperature in an inverted position for $24 \mathrm{~h}$.

The fish sample was dissected to open up the stomach. With the aid of a sterile blade, the stomach was cut into two and two pairs of sterile forceps were used to turn the stomach inside-out. A sterile swab was used to rub the exposed inner surface of the stomach and cultured on nutrient agar after which streaking was carried out using a sterile inoculating loop. The plates were then incubated at room temperature for $24 \mathrm{~h}$. Characterization of the organisms was based on two criteria:

- Cultural and morphological characteristics of the colonies

- Biochemical characteristics

All the isolates were cultured on the prepared medium in duplicates and incubated aerobically at $37^{\circ} \mathrm{C}$. The colonies were observed on the agar medium plates while the cell morphology was observed microscopically after staining. Various biochemical tests were carried out on the bacterial isolates for possible identification. One milliliter of both culture of each isolate was used for all the tests except otherwise stated. 
Gram staining was carried out by the methods of Harrigan and McCance (1966). Motility, catalase and oxidase tests were carried out on the isolates using the methods stated by Seeley and VanDemark (1972). A delayed reaction was recorded as negative.

\section{RESULTS AND DISCUSSION}

Skin: Table 1 and 2 show the result of various biochemical test carried out for the identification of the bacterial isolates. In skin of C. gariepinus, only Bacillus macerans was isolated in T2 on day 14 but did not occur on day 28 (Table 3). Bacteria such as Streptococcus faecium, S. zymogenes, Bacillus cereus and Proteus mirabilis only occurred in the natural microflora but did not occur in C. gariepinus exposed to the two concentrations of nickel bicarbonate. Some bacteria such as B. cereus, P. purela, Micrococcus acidiophilus, Aerobacter aerogenes, Proteus morganii, P. mirabilis (day 14) and Pseudomonas fragii, $P$. putida, $P$. florescence and $A$. aerogenes (day 28) occurred in $0.06 \mathrm{mg} \mathrm{L}^{-1}$ Nibut were not found in $0.08 \mathrm{mg} \mathrm{L}^{-1} \mathrm{Ni}$.

On day 14 , four bacteria were isolated from the skin microflora of C. gariepinus in T2: B. macerans, Streptococcus zymogenes, $P$ seudomonas florescence and $P$. fragii while on day 28 , Pseudomonas gellucidium and Proteus vulgaricus were isolated.

Gut: In the natural gut microflora, only Pseudomonas faecium was isolated in $\mathrm{T} 2$ day 14 . Other bacteria constituting the natural microflora did not occur in the two treatments of $\mathrm{Ni}$ on day 14 and 28. Enterobacter aerogenes occurred in the two treatments of $\mathrm{Ni}$ while the following occurred in T1 only: S. zymogenes (day 14) and Pseudomonas purela, P. mullei, Serratia marscences and

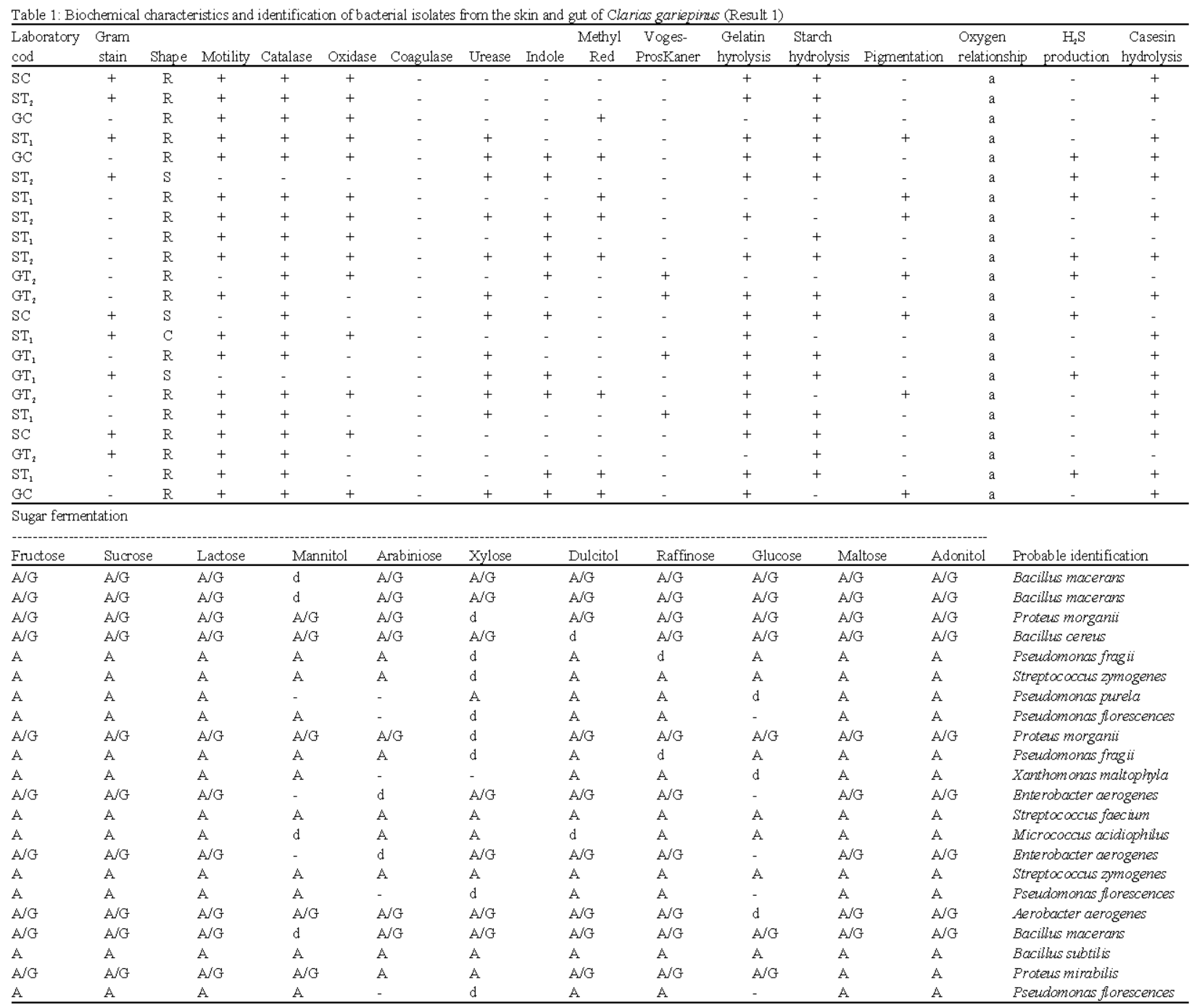


Res. J. Applied Sci., 7 (6): 322-328, 2012

\begin{tabular}{|c|c|c|c|c|c|c|c|c|c|c|c|c|c|c|c|c|}
\hline $\begin{array}{l}\text { Laboratory } \\
\text { cod }\end{array}$ & $\begin{array}{l}\text { Gram } \\
\text { stain }\end{array}$ & Shape & Motility & Catalase & Oxidase & Coagulase & $e$ Urease & Indole & $\begin{array}{c}\text { Methyl } \\
\text { Red }\end{array}$ & $\begin{array}{l}\text { Voges- } \\
\text { ProsKaner }\end{array}$ & $\begin{array}{l}\text { Gelatin } \\
\text { hyrolysis }\end{array}$ & $\begin{array}{c}\text { Starch } \\
\text { hydrolysis }\end{array}$ & Pigmentation & \multicolumn{3}{|c|}{ relationship production hydrolysi } \\
\hline$\overline{\mathrm{ST}_{1}}$ & - & $\mathrm{R}$ & + & + & + & - & + & + & + & - & + & + & - & a & - & + \\
\hline $\mathrm{ST}_{1}$ & - & $\mathrm{R}$ & + & + & - & - & + & - & - & - & + & + & - & a & - & + \\
\hline $\mathrm{ST}_{1}$ & - & $\mathrm{R}$ & + & - & - & - & - & + & + & - & - & + & + & a & - & - \\
\hline $\mathrm{GT}_{1}$ & - & $\mathrm{R}$ & + & + & + & - & - & - & + & - & - & - & + & a & + & - \\
\hline $\mathrm{ST}_{1}$ & - & $\mathrm{R}$ & + & + & + & - & + & + & + & - & + & - & + & a & - & + \\
\hline $\mathrm{GT}_{1}$ & - & $\mathrm{R}$ & + & + & - & - & - & - & + & + & + & + & - & a & - & - \\
\hline $\mathrm{GT}_{1}$ & - & $\mathrm{R}$ & + & + & - & - & + & - & - & + & - & - & + & a & - & - \\
\hline $\mathrm{GT}_{1}$ & - & $\mathrm{R}$ & + & + & - & - & + & - & - & - & + & + & \multirow{2}{*}{-} & a & - & + \\
\hline $\mathrm{ST}_{2}$ & - & $\mathrm{R}$ & - & - & + & - & + & - & + & + & + & + & & a & - & + \\
\hline $\mathrm{GT}_{2}$ & + & $\mathrm{C}$ & - & + & - & - & + & - & - & - & - & + & - & a & - & + \\
\hline $\mathrm{GT}_{2}$ & + & $\mathrm{S}$ & - & + & - & - & + & + & - & - & + & + & + & a & + & - \\
\hline $\mathrm{ST}_{2}$ & - & $\mathrm{R}$ & + & + & + & - & + & + & + & - & - & + & - & a & - & - \\
\hline $\mathrm{GC}$ & - & $\mathrm{R}$ & + & + & + & - & + & - & - & - & + & + & + & a & + & + \\
\hline $\mathrm{SC}$ & + & $\mathrm{R}$ & + & + & + & - & + & - & - & - & + & + & + & a & - & + \\
\hline $\mathrm{GC}$ & - & $\mathrm{R}$ & + & + & + & - & - & + & - & - & + & + & + & a & - & - \\
\hline $\mathrm{SC}$ & - & $\mathrm{R}$ & + & + & - & - & - & + & + & - & - & + & - & a & - & + \\
\hline GC & + & $\mathrm{R}$ & + & + & + & - & - & - & - & - & + & + & \multirow{2}{*}{-} & a & - & + \\
\hline $\mathrm{SC}$ & + & $S$ & - & - & - & - & + & + & - & - & + & + & & $\mathrm{a}$ & + & + \\
\hline \multicolumn{17}{|c|}{ Sugar fermentation } \\
\hline Fructose & \multicolumn{2}{|l|}{ Sucrose } & Lactose & \multicolumn{2}{|c|}{ Mannitol } & Arabiniose & Xylose & Dulc & citol & Raffinose & Glucos & $\mathrm{Ma}$ & Ado & nitol Proba & able identific & cation \\
\hline $\bar{A}$ & A & & $\mathrm{A}$ & A & 2 & $\Delta$ & $\mathrm{d}$ & A & & $\mathrm{d}$ & A & $\mathrm{A}$ & A & Psend & domonas fro & \\
\hline $\mathrm{A} / \mathrm{G}$ & $\mathrm{A} / \mathrm{G}$ & & $\mathrm{A} / \mathrm{G}$ & $\mathrm{A} / \mathrm{G}$ & & $\mathrm{A} / \mathrm{G}$ & $\mathrm{A} / \mathrm{G}$ & $\mathrm{A} / \mathrm{G}$ & & $\mathrm{A} / \mathrm{G}$ & d & A & $\mathrm{A} / \mathrm{G}$ & Aerob & bacter aero & ogenes \\
\hline A & A & & A & - & - & & $d$ & A & & $\mathrm{A}$ & A & $\mathrm{A}$ & $\mathrm{A}$ & Psevio & domonas pu & itida \\
\hline A & A & & A & - & - & & A & A & & A & d & $\mathrm{A}$ & A & Psent & domonas pu & urela \\
\hline A & A & & A & A & . & & d & A & & A & - & $\mathrm{A}$ & A & $P_{\text {send }}$ & domonas flo & orescenc \\
\hline $\mathrm{A} / \mathrm{G}$ & $\mathrm{A} / \mathrm{G}$ & & $\mathrm{A} / \mathrm{G}$ & $\mathrm{A} / \mathrm{G}$ & & $\mathrm{A} / \mathrm{G}$ & $\mathrm{A} / \mathrm{G}$ & $\mathrm{A} / \mathrm{G}$ & & $\mathrm{A} / \mathrm{G}$ & $\mathrm{A} / \mathrm{G}$ & $\mathrm{A} / \mathrm{C}$ & $\mathrm{A} / \mathrm{G}$ & Serra & utia marscen & nees \\
\hline A & A & & A & A & - & & d & A & & A & - & d & A & Psent & domonas mu & ullei \\
\hline $\mathrm{A} / \mathrm{G}$ & $\mathrm{A} / \mathrm{G}$ & & $\mathrm{A} / \mathrm{G}$ & - & d & trat & $\mathrm{A} / \mathrm{G}$ & $\mathrm{A} / \mathrm{G}$ & & $\mathrm{A} / \mathrm{G}$ & - & $\mathrm{A} / \mathrm{C}$ & $\mathrm{A} / \mathrm{G}$ & Enter & robacter aer & rogenes \\
\hline A & A & & A & A & t & A & d & d & & A & A & A & A & Psent & domonas ge & illucidiun \\
\hline A & A & & A & A & st & A & d & A & & A & A & A & A & Staph & ylococcus $p$ & parasiticus \\
\hline A & A & & A. & A & ts & A & A & A & & A & A & A & A & Strept & tococcus fat & lecium \\
\hline $\mathrm{A} / \mathrm{G}$ & $\mathrm{A} / \mathrm{G}$ & & $\mathrm{A} / \mathrm{G}$ & - & c & 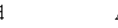 & $\mathrm{A} / \mathrm{G}$ & $\mathrm{A} / \mathrm{G}$ & & $\mathrm{A} / \mathrm{G}$ & - & $\mathrm{A} / \mathrm{C}$ & $\mathrm{A} / \mathrm{G}$ & Prote & aus vulgarica & \\
\hline A & A & & A & A & st & A & A & A & & A & A & $\mathrm{A}$ & A & Psent & domonas au & ureginosa \\
\hline $\mathrm{A} / \mathrm{G}$ & $\mathrm{A} / \mathrm{G}$ & & $\mathrm{A} / \mathrm{G}$ & $\mathrm{A} / \mathrm{G}$ & & $A / G$ & $\mathrm{~A} / \mathrm{G}$ & d & & $\mathrm{A} / \mathrm{G}$ & $\mathrm{A} / \mathrm{G}$ & $\mathrm{A} / \mathrm{C}$ & $A / G$ & Bacill & hus cereus & \\
\hline $\mathrm{A} / \mathrm{G}$ & $\mathrm{A} / \mathrm{G}$ & & $\mathrm{A} / \mathrm{G}$ & $\mathrm{A} / \mathrm{G}$ & & $\Delta / G$ & d & $\mathrm{A} / \mathrm{G}$ & & $\mathrm{A} / \mathrm{G}$ & $\mathrm{A} / \mathrm{G}$ & $\mathrm{A} / \mathrm{C}$ & $\mathrm{A} / \mathrm{G}$ & Prote & zus morgani & \\
\hline $\mathrm{A} / \mathrm{G}$ & $\mathrm{A} / \mathrm{G}$ & & $\mathrm{A} / \mathrm{G}$ & $\mathrm{A} / \mathrm{G}$ & 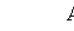 & A & A & $\mathrm{A} / \mathrm{G}$ & & $\mathrm{A} / \mathrm{G}$ & $\mathrm{A} / \mathrm{G}$ & $\mathrm{A}$ & $\mathrm{A}$ & Prote & aus mirabilis & \\
\hline $\mathrm{A} / \mathrm{G}$ & $\mathrm{A} / \mathrm{G}$ & & $\mathrm{A} / \mathrm{G}$ & d & & $\mathrm{A} / \mathrm{G}$ & $\mathrm{A} / \mathrm{G}$ & $\mathrm{A} / \mathrm{G}$ & & $\mathrm{A} / \mathrm{G}$ & $\mathrm{A} / \mathrm{G}$ & $\mathrm{A} / \mathrm{C}$ & $\mathrm{A} / \mathrm{G}$ & Bacill & lus maceran & \\
\hline A & A & & A & A & t & A & A & A & & A & A & A & A & Strept & tococcus zy & mogenes \\
\hline
\end{tabular}

Table 3: Isolates and sites of isolation in Clarias gariepinus treated with $\mathrm{Ti}\left(0.6 \mathrm{mg} \mathrm{L}^{-1}\right.$ $\mathrm{NiHBCO})$ and $\mathrm{T} 2\left(0.8 \mathrm{mg} \mathrm{L}^{-1} \mathrm{NiHBCO}\right)$

\begin{tabular}{|c|c|c|c|c|c|c|}
\hline \multirow[b]{2}{*}{ Isolates } & \multicolumn{2}{|c|}{ Control } & \multicolumn{2}{|l|}{$\mathrm{T} 1$} & \multicolumn{2}{|l|}{$\mathrm{T} 2$} \\
\hline & Skin & Gut & Skin & Gut & Skin & Gut \\
\hline Aerobacter aerogenes & + & + & + & & + & \\
\hline Bacillus cereus & + & & + & & & \\
\hline $\begin{array}{l}\text { B. macerans } \\
\text { B. subtilis }\end{array}$ & + & + & & & + & + \\
\hline Enterobacter aerogenes & + & & & + & + & + \\
\hline Micrococcus acidiophilus & + & & + & & & \\
\hline Proteus mirabilis & + & & + & & & \\
\hline Proteus morganii & + & & + & & & \\
\hline Proteus vulgaricus & & & & & + & \\
\hline$P_{\text {seudomonas aeruginosa }}$ & & + & & & & \\
\hline P. florescences & & + & + & & + & + \\
\hline P. fragii & & + & + & + & + & \\
\hline P. gellucidium & & & & & + & \\
\hline P.mullei & & & & + & & \\
\hline P. purela & & & + & + & & \\
\hline P.putida & & & + & & & \\
\hline Serratia marscences & & & & + & & \\
\hline Staphilococcus parasiticus & & & & & & + \\
\hline Streptococcus faecium & + & & & & & + \\
\hline S.zymogenes & + & & & + & + & \\
\hline Xanthomonas maltophila & + & & & & & + \\
\hline
\end{tabular}

Enterobacter aerogenes (day 28). Xanthomonas maltophila was the only entrant in T2 (day 14) while Staphilococcus parasiticus and Streptococcus faecium occurred in T2 (day 28). Exposure of C. gariepinus to $\mathrm{Ni}$ toxicity had a profound effect on the composition and abundance of skin and gut microflora (Table 4-6).

Tam and Wong (1995) stated that heavy metal contamination in aquatic environment is a critical concern due to the toxicity of metals and their accumulation in aquatic habitats. Although, metals such as Copper $(\mathrm{Cu})$ and Zinc (Zn) are generally regarded as essential trace metals in view of their metabolic activities in organisms, other metals like Cadmium (Cd), Lead (Pb), Nickel (Ni) and Mercury (Hg) exhibit extreme toxicity even at trace levels (Merian, 1991; DWAF, 1996).

Metal contamination in aquatic ecosystems has long been recognized as a serious pollution problem. Most of the essential metals are toxic when supplied in high concentration at the optimum levels. Among the aquatic fauna, fish is the most susceptible to heavy metal toxicants (Nwaedozie, 1998) and so are more vulnerable to metal contamination than any other aquatic fauna.

Bacteria causing spoilage of fish are part of the natural flora and predominant among them are Pseudomonas sp., Achromobacter sp., Flavobacterium sp., Micrococcus sp. and Bacillus sp. Some of these bacteria can grow at low temperature, first on the surface and later penetrate into the flesh or tissue. Different kinds of bacteria are found in the intestinal system which are known as gut flora: when the balance of the gut flora is disturbed, it results in unpleasant gastrointestinal symptoms in man and aquatic organisms. 
Res. J. Applied Sci., 7 (6): 322-328, 2012

\begin{tabular}{|c|c|c|c|c|c|c|c|c|}
\hline \multirow[b]{2}{*}{ Days } & \multirow[b]{2}{*}{ Ni concentration } & \multicolumn{7}{|c|}{ Bacteria isolated } \\
\hline & & $\begin{array}{l}\text { Aerobacter } \\
\text { aerogenes }\end{array}$ & Bacillus cereus & B. macerans & $\begin{array}{l}\text { Micrococcus } \\
\text { acidiophilus }\end{array}$ & $\begin{array}{l}\text { Proteus } \\
\text { mirabilis }\end{array}$ & $\begin{array}{c}\text { Proteus } \\
\text { morganii }\end{array}$ & $\begin{array}{c}\text { Proteus } \\
\text { vulgaricus }\end{array}$ \\
\hline \multirow[t]{3}{*}{14} & Control & - & - & 5 & - & - & - & - \\
\hline & $\mathrm{T} 1: 0.06 \mathrm{mg} \mathrm{L}^{-1}$ & 2 & 8 & - & 1 & 2 & 2 & - \\
\hline & $\mathrm{T} 2: 0.08 \mathrm{mg} \mathrm{L}^{-1}$ & - & - & 5 & - & - & - & - \\
\hline \multirow[t]{4}{*}{28} & Control & - & 8 & - & - & 5 & - & - \\
\hline & $\mathrm{T} 1: 0.06 \mathrm{mg} \mathrm{L}^{-1}$ & 2 & - & - & - & - & - & - \\
\hline & $\mathrm{T} 2: 0.08 \mathrm{mg} \mathrm{L}^{-1}$ & - & - & - & - & - & - & 5 \\
\hline & & \multicolumn{7}{|l|}{ Bacteria isolated } \\
\hline Days & Ni concentration & P. florescences & P. fragii & P. gellucidium & P. purela & P. putida & reptococcus faecium & S. zymogenes \\
\hline \multirow[t]{3}{*}{14} & Control & - & - & - & - & - & 12 & - \\
\hline & $\mathrm{T} 1: 0.06 \mathrm{mg} \mathrm{L}^{-1}$ & - & - & - & 5 & - & - & - \\
\hline & $\mathrm{T} 2: 0.08 \mathrm{mg} \mathrm{L}^{-1}$ & 15 & 3 & - & - & - & - & 12 \\
\hline \multirow[t]{3}{*}{28} & Control & - & - & - & - & - & - & 2 \\
\hline & $\mathrm{T} 1: 0.06 \mathrm{mg} \mathrm{L}^{-1}$ & 15 & 3 & - & - & 10 & - & - \\
\hline & $\mathrm{T} 2: 0.08 \mathrm{mg} \mathrm{L}^{-1}$ & - & - & 5 & - & - & - & - \\
\hline
\end{tabular}

Table 5: Abundance of bacteria present on gut of Clarias gariepinus exposed to two concentrations of Ni

\begin{tabular}{|c|c|c|c|c|c|c|c|c|}
\hline Day & Ni concn & B. macerans & Enteroba & erogenes 1 & Proteus morganii & Pseudomonas aeruginosa & P. faecium & P. fragii \\
\hline \multirow[t]{3}{*}{14} & Control & - & & & 2 & - & 15 & 3 \\
\hline & $\mathrm{T} 1: 0.06 \mathrm{mg} \mathrm{L}^{-1}$ & - & & & - & - & - & - \\
\hline & $\mathrm{T} 2: 0.08 \mathrm{mg} \mathrm{L}^{-1}$ & - & & & - & - & 15 & - \\
\hline \multirow[t]{3}{*}{28} & Control & 5 & & & - & 6 & - & - \\
\hline & $\mathrm{T} 1: 0.06 \mathrm{mg} \mathrm{L}^{-1}$ & - & & & - & - & - & - \\
\hline & $\mathrm{T} 2: 0.08 \mathrm{mg} \mathrm{L}^{-1}$ & - & & & - & - & - & - \\
\hline$\underline{\text { Days }}$ & Ni concn & P. mullei & P. purela & $\begin{array}{c}\text { Serratia } \\
\text { marscences }\end{array}$ & $\begin{array}{l}\text { Staphylococcus } \\
\text { parasiticus }\end{array}$ & $\begin{array}{c}\text { Streptococcus } \\
\text { faecium }\end{array}$ & umogenes & $\begin{array}{c}\text { Xanthomonas } \\
\text { maltophila }\end{array}$ \\
\hline \multirow[t]{3}{*}{14} & Control & - & - & - & - & - & - & - \\
\hline & $\mathrm{T} 1: 0.06 \mathrm{mg} \mathrm{L}^{-1}$ & - & - & - & - & - & 2 & - \\
\hline & $\mathrm{T} 2: 0.08 \mathrm{mg} \mathrm{L}^{-1}$ & - & - & - & - & - & - & 1 \\
\hline \multirow[t]{3}{*}{28} & Control & - & - & - & - & - & - & - \\
\hline & $\mathrm{T} 1: 0.06 \mathrm{mg} \mathrm{L}^{-1}$ & 3 & 5 & 2 & - & - & - & - \\
\hline & $\mathrm{T} 2: 0.08 \mathrm{mg} \mathrm{L}^{-1}$ & - & - & - & 20 & 12 & - & \\
\hline
\end{tabular}

Table 6: Becterial counts and physiologic identification of strains isolated from TSA plates sampled from clarias gariepinus exposed to $0.08 \mathrm{mg} \mathrm{L}^{-1}$ of nikel bicarbonate $\left(\mathrm{T}_{1}\right)$

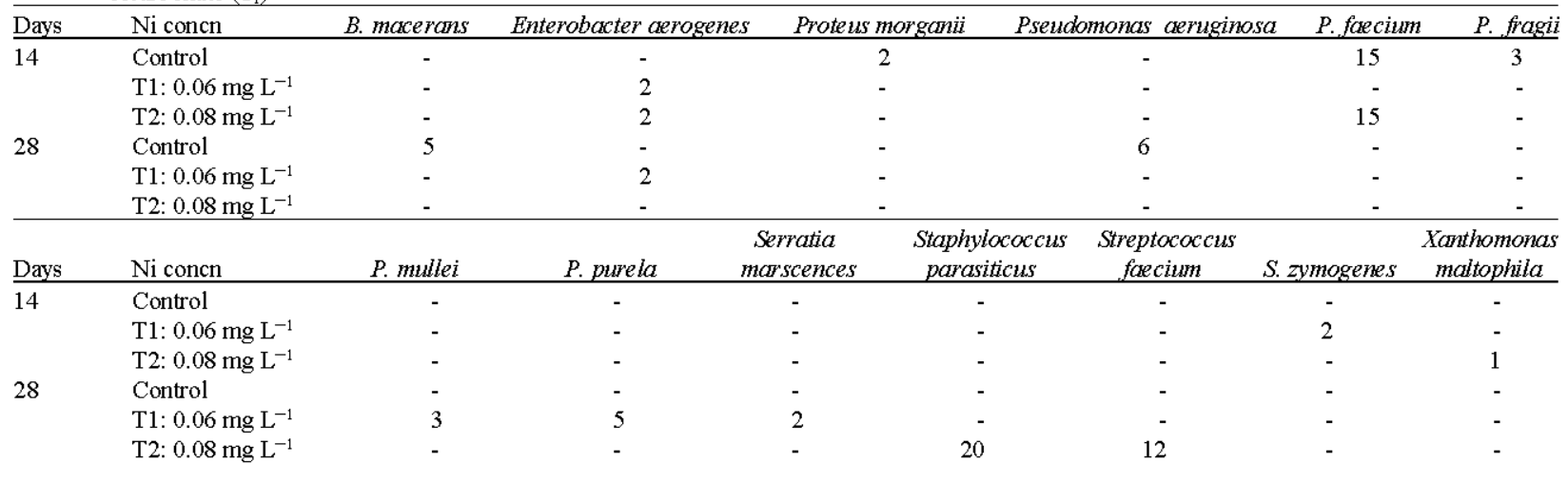

Nickel is a natural ubiquitous element of the earth and in water (Snodgrass, 1980). Toxicity is the capacity to cause injury to a living organism defined with reference to the quality of chemical administered. Nickel may be absorbed as the soluble Nickel ion $\left(\mathrm{Ni}^{+2}\right)$ while sparingly soluble nickel compound may be phagocytized. Nickel ions tend to be soluble at $\mathrm{pH}$ of 6.5 and above 6.7 they mostly form insoluble nickel hydroxides (Dallas and Day, 1993).
In aquatic ecosystems, dissolved $\mathrm{Ni}$ concentrations are generally between 0.005 and $0.010 \mathrm{mg} \mathrm{L}^{-1}$ (Galvin, 1996). The toxicity of $\mathrm{Ni}$ to aquatic life has been shown to vary significantly with species of organisms, $\mathrm{pH}$ and water hardness (Dallas and Day, 1993; Birge and Black, 1980). Nickel toxicity is generally low (Khangarot and Ray, 1990) but elevated concentrations have been reported to cause sub lethal effects. Nickel is readily distributed throughout the body but may be affected by route of 
exposure, the chemical form and the time after exposure (Coogan et al., 1989). The chemical form and its site of deposition in the lungs will affect the extent of absorption (ATSDR, 1988). The kidney and lungs are the primary sites of accumulation of nickel, other organs such as the spleen, liver, heart and testes may also accumulate the metal to a much lesser rate. Much of the toxicity of nickel may be associated with its interference in the physiological processes of manganese, zinc, calcium and magnesium (Coogan et al., 1989).

Nickel may be removed from portions of the respiratory tract through mucociliary transport resulting in the material entering the gastrointestinal tract. Although, nickel is poorly absorbed from the gastrointestinal tract, dietary exposure and exposure via drinking water provide most of the intake of nickel and nickel compounds (Coogan et al., 1989).

Majority of Bacillus species have generally been thought to be unsuitable for colonization of the gut due to their instability in the harsh $\mathrm{pH}$ environment of the bile, particularly human bile. Bacillus coagulans was found to survive and colonize the gastrointestinal tract such as bile environment and grown in a low $\mathrm{pH}$ range. The human bile environment is different from the bile environment of animal models and there has not been any accurate description of $B$. coagulans growth in human gastrointestinal tract.

The purified population of $B$. coagulans has an optimal growth temperature of $<45^{\circ} \mathrm{C}$ for example; the isolated population of $B$. coagulans has an optimal growth temperature of $20^{\circ} \mathrm{C}$, more preferably $36^{\circ} \mathrm{C}$ and most preferably $37^{\circ} \mathrm{C}$. The strain grows at a low $\mathrm{pH}$ such as $\mathrm{pH}$ conditions found in the gastrointestinal tract of a mammal. Another experiment was carried out on the microbiological state of fish feed, water and skin of European catfish, Silurus glanis fry during intensive rearing in a pond. The number of heterotrophic bacteria cultured on broth agar at a temperature of 22 and $37^{\circ} \mathrm{C}$, heterotrophic bacteria cultured on TGY medium at a temperature of $25^{\circ} \mathrm{C}$. Bacteria such as Pseudomonas flourescens, Aeromonas hydrophila and Pseudomonas aeruginosa were found in the water. Pseudomonas fluorescens was found in the feed while Pseudomonas aeruginosa and Aeromonas hydrophila were not observed in the feed. Potentially pathogenic bacteria were observed in numbers ranging from several to several dozen on the skin surface (Iwona and Monika, 2004).

Itoi et al. (2006), carried out a study on chitinolytic bacteria in the intestinal tract of Japanese coastal fishes. These bacteria from several coastal fish species were screened on $1 / 20$ PYBG medium containing $0.2 \%$ colloidal chitin and 361 bacteria capable of decomposing colloidal chitin were isolated. These isolates were screened on media containing either $0.5 \%$ alpha-chitin resulting in the identification of $31 \beta$-chitinolytic and $275 \beta$-chitinolytic bacterial isolates. Phylogenetic that is the $\beta$-chitinolytic bacteria belonging to the Vibrionaceae formed a separate cluster from the non- $\beta$-chitinolytic bacteria in the Vibrionaceae.

\section{CONCLUSION}

It is conclude that the purpose of this study was to investigate the effect of nickel on the gill, gut and skin of Clarias gariepinus. This is important to be able to explore the use of these microflora as potential indicators of metals pollution in aquatic environment. Also, the reaction of the microflora of Clarias gariepinus under stressor agents such as exposure to nickel.

\section{REFERENCES}

ATSDR, 1988. Toxiological profile for Nickel ATSD/U.S Public Health Service. ATSDR/TP-88/19.

Agbozu, I.E. and I.K.E. Ekweozor, 2001. Heavy metals in a nontidal freshwater swamp in the Niger Delta areas of Nigeria. Afr. J. Sci., 2: 175-182.

Allen, P., 1995. Chronic accumulation of cadmium in the edible tissues of Oreochromis aureus (Steindachner): Modification by mercury and lead. Arch. Environ. Contam. Toxicol., 29: 8-14.

Annune, P.A. and T.T. Iyaniwura, 1993. Accumulation of two trace metals in the tissues of fresh water fishes, Oreochromis niloticus and Clarias gariepinus. $\mathrm{T}$. Aqua. food Technol., 2: 5-18.

Baranowska-Bosiacka, I., A.J. Hlynczak and B. Machalinski, 2000. The impact of lead ions on metabolism of erythrocytes. Med. Pr., 51: 59-65.

Birge, W.S. and J.A. Black, 1980. Aquatic Toxicology of Nickel. In: Nickel in the Environment, Nriagu, J.O. (Ed.). John Wiley and Sons Inc., USA., pp: 349-366.

Coogan, T.P., D.M. Latta, E.T. Snow and M. Costa, 1989. Toxicity and carcinogenicity of nickel compounds. Crit. Rev. Toxicol., 19: 341-384.

Cummings, J.H., G.R. Gibson and G.T. Macfarlane, 1989. Quantitative estimates of fermentation in the hindgut of man. Acta Vet. Scand., 86: 76-82.

DWAF, 1996. South African Water Quality Guidelines. 2nd Edn., Aquatic Ecosystems, Canada, Pages: 159.

Dallas, H.F. and J.A. Day, 1993. The effect of water quality variables on riverine ecosystems: A review. Water Research Commission Report No. 351, pp: 200.

Galvin, R.M., 1996. Occurrence of metals in water: An overview. Water S.A. 2: 7-18.

Gibson, G.R. and M.B. Roberfroid, 1995. Dietary modulation of the human colonic microbiota: Introducing the concept of prebiotics. J. Nutr., 125: 1401-1412. 
Harrigan, W.F. and M.E. McCance, 1966. Laboratory Methods in Microbiology. Academic Press, London, Pages: 362.

Horsley, R.W., 1977. A review of the bacterial flora of teleosts and elasmobranchs, including methods for its analysis. J. Fish Biol., 10: 529-533.

Itoi, S., T. Okamura, Y. Koyama and H. Sugita, 2006. Department of marine science and resources. Nihon Univ. Kanagawa, Japan, 52: 1158-1163.

Iwona, G. and H. Monika, 2004. The microbiological state of fish feed, water and Silurus glanis L. skin of fry during intensive rearing. Bull. Sea Fish. Inst., 1: 3-14.

Khangarot, B.S. and P.K. Ray, 1990. Correlation between heavy metal, acute toxicity values in Daphnia magna and fish. Bull. Environ. Contam. Toxicol., 38: 722-726.

Merian, E., 1991. Metals and their Compounds in the Environment: Occurrence Analysis and Biological Relevance. 1st Edn., John Wiley and Sons Inc., New York.

Moriarty, D.J.W., 1990. Measurements of Bacterial Biomass in Sandy Sediment. In: Biogeochemistry of Ancient and Modern Environments, Trudinger, P.A., M.R. Walter and B.J. Ralph (Eds.). Australian Academy of Science, Canberra, Australia, pp: 131-138.

Nwaedozie, J.M., 1998. The determination of heavy metal pollution in some fish samples from River Kaduna. J. Chem. Soc. Nigeria, 23: 21-23.
Olaifa, F.G., A.K. Olaifa and T. E. Onwude, 2004. Lethal and sub-lethal effects of copper to the African Cat fish (Clarias gariepnus). Afr. J. Biomed. Res., 7: $65-70$.

Olojo, E.A.A., K.B. Olurin, G. Mbaka and A.D. Oluwemimo, 2005. Histopathology of the gill and liver tissues of the African catfish Clarias gariepinus exposed to lead. Afr. J. Biotechnol., 4: $117-122$.

Pagenkopf, G.K., 1983. Gill surface interaction model for trace metal toxicity to fish: Role of complexation, $\mathrm{pH}$ and water hardness. Environ. Sci. Technol., 17: 342-347.

Seeley Jr., H.W. and P.J. VanDemark, 1972. Microbes in Action: A Laboratory Manual of Microbiology. 2nd Edn., Freeman, San Francisco, USA.

Snodgrass, W.F., 1980. Distribution and Behaviour of Nickel in the Aquatic Environment. In: Nickel in the Environment, Nriagu, J.O. (Ed.). Wiley and Sons Inc., New York, pp: 203-274.

Tam, N.F.Y. and Y.S. Wong, 1995. Spatial and temporal variations of heavy metal contaminations in sediments of a mangrove swamp in Hong Kong. Mar. Pollut. Bull., 11: 254-261.

Van Vuren, H., M. van der Merwe and H.H. du Preez, 1994. The effect of copper on the blood chemistry of Clarias gariepinus (Clariidae). Ecotoxicol. Environ. Saf., 29: 187-199. 